DUMITRU LOȘONȚI

\title{
CUVINTE PROVENITE DE LA ONOMATOPEE (II)*
}

BONTĂNÍ. Verbul a bontăni 'a face zgomot lovind în ceva, a bocăni, a ciocăni; a lovi cu putere pe cineva', care circulă în Moldova, Bucovina, Crișana, Transilvania, este lăsat în TDRG ${ }^{1}, \mathrm{DA}, \mathrm{CADE}$ și MDA fără explicație etimologică. SDLR îl compară cu a bontălui [= a buntului], a bocăni și cu ung. bontani 'a desface, a nimici'. DM îl consideră împrumut din ung. bántani [corect: bánt 'a bate, a lovi, a atinge', TDRG ${ }^{3}$ și DELR îl socotesc derivat de la o bază onomatopeică. DEX ${ }^{1,2}$, CDER și BDG nu-l înregistrează.

Explicația din maghiară nu este plauzibilă. De altfel, cuvântul nu a fost reținut (printre împrumuturile maghiare în română) de Tamás E.

După părerea noastră, este un derivat, cu suf. -ăni, de la forma interjecțională * bont. Pentru $\operatorname{bonc}(a)$ 'interjecție onomatopeică, imitând zgomotul produs de bătaia ciocanului s. de cineva care se împiedică’ (DA), *bont, vezi infra, *țâșc, țâșt.

BUIȘTÍ， BUJDÍ， BUJDICÁ，BUSTÍ，FÂSTTICÁ，FUȘTICÁ，PẤSTTTTă PUȘTICÁ, VIȘTÍ, VÂȘTICÁ, VUȘTICÁ. A bujdi 'a țâșni, a năvăli afară, a ieși cu putere, a bui; a năpădi, a podidi (sângele)' se găsește în DA din mai multe surse, printre care și LB, iar a bujdica 'idem', doar din LB. Aceste forme verbale au fost notate și de Emil Petrovici, prima, în Petrila HD (bujdește: ALR II SN IV h. 1119/833), iar cea de-a doua, în Feneș $\mathrm{AB}$ (bujdică sângele din el departe: ibid. h. 1119/102). A bujdi mai figurează în Bărbuț DGO și în Popa Voroave 38.

După mențiunea ,etimologia necunoscută”, în DA se dă, între paranteze rotunde, completarea: „Probabil onomatopee; PONTBRIANT îl aseamănă cu ung. buzdúl 'clocotește', cf. șì bozsog 'idem', (fel-)buzzanni 'a țâșni')”.

CADE îl dă fără etimologie. SDLR îl consideră „var. din ciujdesc”, comparându-1 (cum vor face și DM, DEX ${ }^{1,2}$, MDA) cu ung. buzdúlni 'a clocoti', iar CDER îl explică din acesta. Pentru TDRG ${ }^{3}$ este „onomatopoetisch”. În DELR se precizează că etimologia este nesigură, fiind vorba, ,probabil”, de un „derivat de la o bază onomatopeică".

Atât în DA, cât și în DELR, a bujdica e lucrat s.v. a bujdi, fără vreo precizare privind modul în care s-a format.

A bujdi este o variantă a lui a buști 'idem' (Ciaușanu Gl, LRg II 20, Bărbuț DGO), rezultată prin sonorizarea grupului consonantic -șt-. A buşti s-a format, cu suf. verbal $-i$, de la interjecția *buști. Pentru interj. bâști > a bâșsti (DA, DELR

\footnotetext{
* Prima parte a acestui studiu a apărut în volumul Din dragoste de dascăl şi de voroavă. Omagiu doamnei profesor Elena Dragoş, la aniversare, Cluj-Napoca, Casa Cărţii de Ştiinţă, 2019, p. 156-166.
} 
etc.), interj. *buşti > a buşti, vezi perechea sinonimă interj. țâşti > a țâști (DLR), interj. țuști > a țuști (DLR).

$\mathrm{N}$-ar fi exclus ca sonorizarea grupului -șt- să se fi produs în interjecția *buști, caz în care a bujdi se explică din *bujdi.

A buiști 'a bui, a da năvală' (Bărbuț DGO) a rezultat prin contaminarea sinonimelor a bui și a buști.

A se fâștica '(reg.) a se furișa' este comparat de CADE cu interjecția fâşti și considerat în DM „onomatopee”. Definit 'a fugi repede, a o tuli, a dispărea pe neobservate', se găsește într-un glosar din Şomcuta Mare MM, Buciumi MM, Chiuzbaia MM, Hideaga MM (vezi LRg I 24). Îl cunoaștem și noi din graiul satului natal (Bonțida CJ).

A se fuștica e atestat cu sensul '(despre pești) a se mișca repede, în toate părțile pe furiș; a porni, a trece ca o săgeată, furișându-se' (vezi MCD I 22), 'a se strecura, a se furișa' (ibid. 173).

Romulus Todoran apreciază că este "derivat de la onomatopeea fuști (fâsști)" (ibid. 22), iar Traian Marcu îl compară cu a fâștica (ibid. 173).

A puștica '(despre sânge) a țașni' se întâlnește în partea de nord-vest a țării. Pentru etimologie, DLR îl compară cu a puşca.

A vâștica, cu var. a vuştica, se găsește în DLR cu sensul 'a se lăsa brusc în jos'. Pentru etimologie, este comparat cu verbul a vâști 1. 'a țâșni pe neașteptate din locul în care se află, luând-o la fugă'; 2. '(prin Banat) a intra cu forța undeva'.

Sensul dat este greșit în loc de 'a țâșni, a se furișa', după cum clar rezultă din citatul ilustrativ: „Când era aproape să-1 ajungă, Salcotea deodată se vâștică pe buricul pământului în jos, în lumea zmeilor".

$\mathrm{Nu}$ poate fi vorba de un derivat cu suf. -ica, cu care dă impresia că s-ar fi format, pentru că lat. -icare (care ar fi devenit în românește -ica), productiv în latinește, n-a mai fost întrebuințat pentru formarea de noi verbe în limbile romanice (vezi Istoria limbii române. Volumul I. Limba latină, București, Editura Academiei, 1965, p. 96).

Este un lucru curios cum autorii DLR-ului nu și-au dat seama că $a$ vuştica derivă de la interjecția vuștic 'cuvânt care sugerează mișcarea făcută de ceva care iese sau dispare repede, care se strecoară undeva' („Vuștic, fată frumoasă, prin pădure deasă" [Vulpea]), cunoscută, ca și $a$ vuștica, din regiunea moților.

După cum a remarcat S. Pușcariu DO 89 , „la foarte multe interjecții, care imită mai ales o mișcare sau o cădere repede, se adaugă, după vocală însă, un element final $c$, care poate are același rost ca elementul fonetic - $t$ în onomatopeele ce imită sunete, d. ex. bâldâbâc, bâltâc, bâzdâc, berbeleac, bustubuc, hâltâc, huștiuluc, popâc, șontâc (cf. ung. sánta 'șchiop'), tâlbâc, țopâc etc.".

Vuștic s-a format din *vuști (cf. infra vâști) prin adăugarea lui -c.

De la asemenea variante interjecționale cu $-c(*$ bujdic $<*$ bujdi $<$ buști, *fâștic (cf. fâstăc 'țuști', fâstâc 'idem': Bărbuț DGO) < fâș̦ti, *fuștic < fuști, *puștic < *puști, *vâșstic < vâști 'cuvânt care sugerează mișcarea bruscă și precipitată a unei ființe care sare, care țâş̦nește de undeva': DLR) s-au mai format a bujdica, a fâștica/a fuștica, a puștica, a vâștica. 
Interjecția pâști 'fâști, țâș̦i', care ne este familiară, nu este atestată în dicționare, cum nu e atestat nici verbul a pâș̦ti 'a țaşnini, a se furișa', de la care s-a derivat, cu suf. neaccentuat -iță, pâștiță (pl. pâștițe) 'zgâtie, copilă zburdalnică' (Mușca AB: Ioan-Nicolae Popa, Vorbe: și bune, și grele, din țărână și din stele, Cluj-Napoca, Editura Curs, 2021, p. 109). Cf. fâşniță.

A viști 'a merge repede' (Râmnicu-Vâlcea VL: LRg. I 88) lipsește nejustificat din DLR.

Poate fi derivat de la posibila formă interjecțională *viști 'țâști, vâșsti' sau o variantă a lui $a$ vâști (vezi supra), care e derivat de la interjecția vâști (vezi supra).

CHIȚCÁN a fost explicat ca împrumut din ung. cickány (Cihac II 564, SDLR, MDA), derivat din a chițcăi (DU, CADE, BDG, Loșonți CEL II 156) cu suf. -an (DM, DEX ${ }^{1.2}$ ). Inițial și Sextil Pușcariu 1-a considerat un derivat de la a chițcăi (vezi Pușcariu DO 91), dar, mai târziu, nu mai este convins de acest lucru, afirmând (în DA): „Pare a fi un derivat, cu suf. -an, din chițcăi (cf. însă ung. cickány 'musaraigne'. CIHAC II 564)". CDER îl înserează între derivatele de la interjecția chiț, cu observația că derivarea acestuia „nu este clară”. DELR îl explică de la verbul a chițcăi, ,cu subst. finalei prin analogie cu guzgan”, iar FCLR IV/1 152, de la interjecția chiț, cu formantul -can, care ar mai exista în bătrâncan 'slăbănog' < bătrân și molcan 'molâu' < moale.

Chițcan nu poate fi reflexul ung. cickány. $\mathrm{Nu}$ avem niciun cuvânt în care $k$ să provină din $c$ - (maghiar). Acesta din urmă a dat în românește ț- (vezi Király Contacte 157). De altfel, chițcan nu figurează în Tamás E. Nu poate fi nici un derivat, cu suf. -an, de la a chițcăi, pentru că rezultatul ar trebui să fie *chițcăian, nu chițcan. Cf. țocoian 'miel care suge de la orice oaie', raportat corect în DLR la verbul a țocăi.

Cum am arătat în CEL II, formantul -can nu există în realitate, bătrâncan fiind o greșeală de copiere în loc de bătrâncău < *bătrânocău < bătrânoc (p. 156), iar molcan poate proveni, ,(prin sincoparea lui $e$ neaccentuat) din *molecan, un derivat de la moleac cu suf. -an, sau din molcel, prin substituirea segmentului fonetic $e l$, interpretat ca sufix, cu suf. -an” (p. 157), ori, cum se dă în DLR, „de la molcuț, cu schimbare de sufix".

Chițcan a putut rezulta din contaminarea verbelor a chițcăi, a chițcăni cu țițcan, reflexul normal al ung. cickány, cuvânt atestat în limba română, dat în DLR ca variantă a lui chițcan (,„tițcan v. chițcan") sau, prin derivare regresivă, de la verbul $a$ chițcăni, verb format, cu suf. -ăni, de la interjecția (reduplicată parțial) chiț c[hiț]. Cf. țâțoran, dat în DLR ca variantă a lui chițoran. Așa apare și în Popa Voroave 134.

CILIGÁIE, CILIGĂÍ́. Forma verbală a ciligăi 'a ciripi', notată de Emil Petrovici în Peștișani GJ (ciligăie bărăbeții: ALR II SN V h. 1462/836), nu e cunoscută de dicționare.

Este o variantă a lui a ciricăi 'idem', verb cunoscut de dicționare (< interj. ciric + suf. - $\breve{a i}$ ), notat în punctele vecine $27,812,833,848$ (vezi harta citată), rezultată prin substituirea lui $r \mathrm{cu} l$ și sonorizarea lui $c$. 
Substantivul ciligaie este cunoscut de DA din Vâlcea cu sensul 'gălăgie' și, pentru etimologie, este comparat cu ung. csellegni 'a face glume, a face drăcii' și cu cileandra, folosit în expresia umblă de-a cileandra = fără nicio grijă, nepăsător, fără niciun capăt.

După mențiunea că etimologia este nesigură, și MDA îl compară cu același verb maghiar.

În DELR, după mențiunea că etimologia este nesigură, se presupune că ar fi rezultat din contaminarea lui cilioaie 'pasăre pestriță', cilehoaie 'pasăre urâtă' cu gaie.

E un derivat regresiv de la a ciligăi.

CRĂNȚĂÍ, CRÂNȚĂÍl. $A$ crănțăi '(despre nisipul din pâinea făcută din făina măcinată după ce a fost ferecată roata morii) a trosni (în dinți)' (Negrești-Oaș SM: ALR II SN IV h. 1069/346) nu figurează în dicționare.

Este un derivat, cu suf. verbal -ăi, de la interjecția cranț. Cf. crănțăni < cranț + suf. -ăni (MDA).

A crânțăi 'idem' (Prundu Bârgăului BN, Marginea SV: ALR II SN IV h. 1069/219, 386) este o variantă, necunoscută nici ea de dicționare, rezultată sub influența sinonimului $a$ crâșca, notat într-un punct vecin (vezi harta citată).

DRONȚĂÍ́, DRUNȚǍÍ. A dronțăi '(despre nisipul din pâinea făcută din făina măcinată după ce a fost ferecată roata morii) a trosni (în dinți)' a fost înregistrat de Emil Petrovici în Boiu Mare MM, Moftinu Mic SM, Groşi MM și Bârsana MM (vezi ALR II SN IV h. 1069/272, 334, 349, 353), iar a drunțăi 'idem', în Voivozi (com. Șimian) BH (vezi ibid. h. 1069/325).

Ambele forme verbale lipsesc nejustificat din DLR.

S-au format, cu suf. verbal -ăi, de la interjecțiile *dronț, respectiv *drunț.

DUDUÍ 1. '(despre pământ, clădiri, ferestre etc.; la pers. 3) a se zgudui, a se cutremura, a bubui'; 2. '(despre motoare, mașini etc. în funcțiune; p. e x t. despre ateliere, fabrici etc.; la pers. 3) a produce un zgomot puternic, sacadat și înfundat; (despre surse de zgomot și fenomene ale naturii) a bubui, a tuna, a răsuna' etc. este explicat ca onomatopee (DU, CADE, DM), „formație onomatopeică” (DEX ${ }^{1,2}$, MDA, DLR), creație expresivă (CDER).

Este un derivat, cu suf. verbal $-i$, de la interjecția (repetată) $d u$ 'cuvânt care redă zgomotul produs de un motor în mișcare, vâjâitul unui foc puternic în sobă etc.' (DLR). Cf. sinonimul bubui, bine explicat în DELR de la interjecția (repetată) $b u$.

DURDUÍ. Verbul a durdui 1. '(Mold. și Trans.) a dudui, a hurui; a face explozie, a bubui'; 2. '(prin Trans.) a tuna' nu are până acum o explicație satisfăcătoare. DU trimite la a durui, iar SDLR, la a dârdâi și a dudui. După CADE și CDER, este o variantă a lui $a$ durui. $\mathrm{DEX}^{1,2}$, BDG și MDA îl compară cu a dudui. DM îl consideră rezultatul contaminării între interjecția $d u r$ și $a d u d u i$, iar DLR, rezultatul contaminării între interjecția dura și a durui. 
Suntem de părere că e vorba de un derivat de la interjecția $d u r$ repetată: $d u r$ $d u[\mathrm{r}]+$ suf. $-i>d u r d u i$.

DURDULĂ, DURDURĂ. După o comunicare din Zagra BN, în DLR se găsește dúrdulă 'ploaie torențială, de scurtă durată, cu multe tunete și trăznete'.

Pentru etimologie, este comparat cu a durdui.

Prin întrebare indirectă, de la informatorii noștri din Zagra și Poienile Zagrei BN am înregistrat forma durdúlă, iar de la cei din Săliștea de Sus MM, localitate apropiată de Zagra și Poienile Zagrei, dúrdură (pl. dúrdure).

După părerea noastră, forma inițială este dúrdură (sau *durdúră), un derivat de la interjecția (reduplicată) dur dur. Variantele durdúlă, dúrdulă au rezultat prin disimilarea $r-r>r$ - $l$.

DURDULÍ 'a se rostogoli' a fost înregistrat de Sever Pop în Straja SV.

În MDA, după mențiunea „fo” [= formație onomatopeică $]$, se face trimitere, prin cf., la interjecția dura.

DLR indică doar că este ,formație onomatopeică’.

E un derivat, cu suf. - $u l i$, de la $d u r d$ [ur], sau, cu suf. -li, de la $d u r d u[\mathrm{r}]$.

DUJUÍ. Verbul a dujui 'a vâjâi' se găsește într-un glosar din comunele Breb și Crăcești MM (v. LRg I 14).

MDA îl reține cu etimologia necunoscută, iar DLR îl compară cu $a$ vâjâi.

E un derivat, cu suf. -ui, de la interjecția * $d u j$ 'vâj'.

FÂSTICÚȚĂ (pl. fâșticúțe) 'apelativ glumeț dat unei persoane scunde și vioaie' a fost semnalat, din Petroșani HD, împreună cu varianta fușticúță și citatul ilustrativ Mai stai locului, măi fâșticuțo!, de M. Homorodean, Glosar regional din mai multe regiuni ale Transilvaniei, în MCD I 256.

Cuvântul nu este derivat de la substantivul fâștic '(mai ales la pl.) lucru, obiect mic și fără importanță', cum menționează autorul citat, ci, fără nicio îndoială, de la verbul a se fâștica (fuștica).

FÂȘNÍ. Verbul a fâșni 'a fura' a fost comunicat de preotul Grigore Crăciunaș, originar din Ciubăncuța CJ (vezi CHEST. II 489/322a, p. 16), și inserat în Coman G1.

MDA îl lasă cu etimologia necunoscută.

De la un informator din Ciubăncuța, noi am înregistrat cuvântul doar cu sensul 'a dispărea repede și pe neobservate, a se furișa, a face o mișcare rapidă' (,s-o fâșnit”). Cf. pașli (var. pâșli) care are același sensuri (vezi DLR).

Este un derivat, cu sufixul verbal -ni, de la interjecția fâșt $(i)$, care, așa cum e definită și în MDA, „sugerează o mișcare rapidă (și neașteptată) ' ": *fâșst(i)ni > (prin sincoparea lui $i$ scurt și reducerea grupului consonantic -ștn- la -șn-) fâșni.

Sextil Pușcariu (DO 107) a presupus existența verbului *a fâșni, de la care e derivat fâșneală 'frou-frou', fâș̦neț 'țanțoș’. 
După cum rezultă din dicționare și din cercetările noastre pe teren, fâșneț, fâșneață (adesea, mai ales fâşneață, substantivat) înseamnă 'iute, sprinten, neastâmpărat, vioi; țanțoş, fudul, mândru de sine, cu nasul pe sus'.

DU și CADE îl înregistrează fără explicație etimologică. După SDLR, este „imit. [= imitativ] d. fâş̧-fâş, ca și foșnesc”. După precizarea „etimologia necunoscută”, în DA se menționează, între paranteze rotunde, ipoteza: „Poate fi un derivat din fâșni = foșni”. MDA îl derivă „din fâșni (puțin folosit) cu suf. -eață " (evident, referindu-se la fâșni = foșni), iar DEX ${ }^{1,2}$ și MDA, din interjecția fâș = foș și suf. -neațăa, sufix care, după câte știm, nu există în limba română. Tot de la această interjecție îl explică și BDG, însă fără a indica vreun sufix. TDRG ${ }^{1,3}$ și CDER nu-l cunosc.

Este cât se poate de clar că doar fâsșneală 'foșnetul fustelor' (frou-frou) este derivat de la fâșni [= foșni], verb format, cu suf. -ni, de la fâș 'cuvânt onomatopeic care imită sunetul produs de mișcarea frunzelor, a hârtiei, a veșmintelor sau a ierbii tăiate de coasă' (DA).

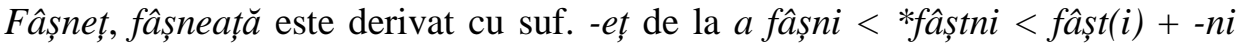
(vezi supra).

FẤȘNIȚĂ 'neastâmpărată', derivat în MDA de la fâș ' 'cuvânt care imită zgomotul produs de mișcarea frunzelor, a hârtiei etc.' cu suf. -niță, este derivat, cu suf. neaccentuat -iță, de la a fâș̦i. Cf. góniță $<$ a se goni (DA), púiță $<$ a pui (Pascu Suf. 259), nu de la pui (cum greșit dă DLR) etc.

FÂȘTÍ. Verbul a fâști 'a dispărea repede și pe neobservate, a se furișa', pe care 1-am înregistrat în Osoi CJ, localitate vecină cu Ciubăncuța, lipsește în dicționare.

S-a format, cu sufixul verbal $-i$, de la interjecția fâșt $(i)$. Cf. sinonimele $a$ bâști $<$ bâșsti, a țâști <țâști etc.

FIȘÓI, FIȘOÍ, PIȘÓI, PIȘOÍ, PIȘOÁIE. În DLR figurează pișoaie cu sensul '(prin Trans.) stropi de apă amestecați cu pietriș care intră prin ochiurile de la piua în care se pune piatra pentru a fi măcinată'.

Este considerat derivat din ,pişa + suf. -oaie".

Indicația „s. f. pl.” este, după toate probabilitățile, opera neinspirată a redactorilor. Din ea rezultă că forma de singular a cuvântului e tot pişoaie.

Verificând sursa bibliografică indicată, VICIU GL. 97, constatăm că există doar forma de plural și cuvântul stropituri a fost înlocuit (nepermis) cu stropi: „Inaintea săgeților în piuă sunt ochiurile, adică o scândură găurită.

Prin «ochiuri» în timpul măcinatului stropește apa amestecată cu pietriș și ajunge dincolo de ochiuri în un loc care se numește hălăștău. Stropiturile aceste, pe care băieșii le numesc pişoaie, le spală cu hurca".

Pişoaie este pl. lui pişoi, cuvânt neutru pe care l-am întâlnit și noi în zona Munților Apuseni, uneori în sintagma cure [cúră] pișoi 'curge abundent'. 
Este un derivat, cu suf. -oi, de la interjecția piș. Cf. bijoi 'izvor care curge pe o țeavă sau pe un jgheab, șipot' (un „derivat, prin suf. -oi, dintr-o tulpină onomatopeică bij- (cf. vâj)”: DA, „derivat onomatopeic” DELR), vâjoi "şuvoi; cascadă, cataractă' $<v \hat{a} j+$ suf. - oi (DLR).

De la pișoi s-a format verbul a pișoi, pe care Emil Petrovici l-a notat în Voivozi (com. Șimian) BH cu sensul '(despre sângele porcului înjunghiat) a țâșni' ([sângele] pișoaie departe [din porc]: ALR II SN IV h. 1119/325). Lipsește nejustificat din DLR.

Verbul se găsește și în Ciauşanu Gl., însă dat ca variantă a lui a fișoi (,,Sângele fișoià = Sângele curgeà ca izvorul, sărià «cocoş», sângele gâlgâià din rană, buştià din rană (buşnià)"). De aici a fișoi, cu varianta a pişsoi, care însă nu apare și la locul ei alfabetic, a fost inclus în MDA, dar lăsat cu etimologia necunoscută.

Precizăm că, după părerea noastră, a fișoi este variantă a lui $a$ pișoi, rezultată prin substituirea lui $p$ cu $f$. Cf. a inpopistra > a înfofistra (vezi Loșonți CPE 180), a plesni (a plezni) > aflesni 'a lovi (cu palma peste obraz)', lăsat în MDA cu etimologia necunoscută.

FLEOSNÍ. Verbul a fleosni 'a lovi pe cineva cu talpa în aşa fel încât să se audă sunetul f l e o s c !' este lucrat de DA s.v. a fleșcăi, care e derivat, cu suf. -ăi , de la interjecția fleașc.

Trebuie să precizăm că acest dicționar cunoaște și interjecția fleosc 'fleașc' (,fleosc: interj. v. fleașc").

MDA, după precizarea că etimologia este nesigură, îl compară cu fleosc!.

Fără nicio îndoială, a fleosni e derivat, cu suf. verbal -ni, de la interjecția fleosc: *fleoscni > (prin reducerea grupului consonantic -scn- la -sn-) fleosni. Cf. (infra) trosni.

FLEOȘCOTÍ 'a produce un zgomot caracteristic umblând prin noroi, prin apă etc.' (Dragomirești MM: Faiciuc D 757) e un derivat, necunoscut în dicţionare, de la interjecția fleoșc $[=$ fleașc $] \mathrm{cu}$ suf. -oti.

FOJGĂí, FOJGĂLUí, FOȘCĂí, FOȘCĂLUí, FOȘGĀí, FUȘCĂLUí, VOJGĂÍ. A foşgăi e cunoscut de dicționare cu sensul 1. '(despre viețuitoare care se găsesc în număr mare pe un spațiu mic și se mișcă neîncetat) a furnica, a foi, a viermui, a mișuna cu zgomot'; 2. 'a manevra cu zgomot foi de hârtie'.

DU și CADE îl înregistrează fără explicație etimologică. După SDLR este „,var. din ung. pezsgeni 'a fojgăi' și rudă cu foșnesc" DA și DM îl derivă din foşăi, prin substituirea suf. -ăi cu -căi DEX $^{1,2}$ și (după mențiunea că etimologia e nesigură) MDA îl compară cu a foșăa. CDER îl menționează printre derivatele de la interjecția fâș. Pentru BDG este cuvânt „onomatopeic”, iar pentru TDRG ${ }^{3}$, derivat de la interjecția $f o s ̧$ ( $f a ̂ s s ̧$, fără a se indica însă sufixul.

Forma a foșcăi 'idem' e dată formă titlu în DA sau variantă în DM, DEX ${ }^{1,2}$, MDA și TDRG ${ }^{3}$. În Marginea SV, a fost înregistrată și cu sensul '(despre zăpadă) a scârțâi sub picioare' (foșcăiește: ALR II SN V h. 1469/386). 
A fojgălui 'idem' e dat în SDLR și TDRG ${ }^{3}$ ca variantă a lui a fojgăi sau lucrat în articol separat și explicat din a fojgăi (MDA).

A foșcălui 'idem' figurează în DA, CDER (printre derivatele de la interjecția fâș), MDA (ca variantă a lui a fojgălui) și în TDRG (ca variantă a lui a fojgăi).

A foşgăi 'idem' (DA, MDA) și a foşgălui 'idem' (MDA) sunt doar variante grafice pentru a fojgăi, respectiv a fojgălui.

A foșcăi și a foșcălui sunt derivate, cu suf. -ăi, respectiv -ăli, de interjecția *foșc 'foș'. Cf. fâș, *fâșc. În DA se consideră că foșcălui s-a format din foșcăi, prin substituirea sufixului -ăi cu -ălui.

Prin sonorizarea grupului consonantic șc, au rezultat variantele a fojgăi și $a$ fojgălui.

Semnalăm și variantele a vojgăi 'idem' (Dragomirești MM: Faiciuc D 772), necunoscută de DLR, rezultată din fojgăi, prin sonorizarea lui $f$, și a fuşcălui 'idem' (Tomoioagă ARM 29), rezultată din a foșcălui, prin substituirea lui $o$ cu $u$.

GĂRĂGÁIE este cunoscut de DA cu sensul 'gălăgie, cârâit de gâște' din MARIAN SE II 12 și explicat din interjecția $g a ̂ r(a)$, dată ca variantă a lui câr, „+ gaie".

Florența Sădeanu (Sufixele colective din limba română cu specială privire asupra repartiției lor, în SMFC III 55) arată că s-a format, cu suf. -aie, de la interjecția repetată ,gâra, gâra".

În MDA e dat ca formație onomatopeică.

După părerea noastră, deși formal s-ar putea explica din interjecția * gara g[ara], cu suf. -aie, este o formă metatezată din *găgăraie, un derivat, cu suf. -ăraie, din interjecția ga ga. Pentru derivatele cu acest sufix, vezi FCLR IV/1 85-88.

JOÍ. Verbul a joi a fost comunicat din Budești MM cu sensul '(despre apa unui râu) a vui' (joiește [scris: joește] râul": CHEST. IV 52/350). Dacă e real, nu rezultatul unei percepții greșite a corespondentului, a rezultat, prin afereza primei silabe, din a vojoi 'idem', formă verbală întâlnită în partea de vest a Transilvaniei și a Crișanei (vezi ALR II SN V h. 1460), lucrată în DLR ca variantă a lui $a$ vâjâi.

E derivat de interjecția voj 'vâj', cu suf. -oi.

JONTĂNÍ. Verbul a jontăni, cunoscut din Transilvania cu sensul 'a face zgomot; s p e c. (despre o lovitură sau bătaie) a suna, a face strepet prin lovitură de secure în lemn', e lăsat în DA și MDA cu etimologia necunoscută.

A rezultat prin contaminarea sinonimelor $a$ bontăni (vezi supra) și a jopăi sau $a$ jopoti (vezi infra).

JOPǍÍ, JOPOTÍ. În MDA, a jopăi 'a bate, a lovi’ e considerat variantă a lui $a$ jupăi, pe care îl derivă de la interjecția jap. Tot de la ea e derivat, cu suf. -oti, a jopoti 'idem'. 
E adevărat că în DA verbele sunt lucrate s.v. jap, dar acolo se dă și varianta joap.

A jopăi și a jopoti sunt derivate, cu suf. -ăi, respectiv -oti, de la joap.

JUPNÍ. Verbul a jupni '(despre oameni, obiecte etc.) a produce un sunet caracteristic prin cădere', înregistrat de Emil Petrovici în Livezi HR (jupnește: jup ALR II SN V h. 1468/574), lipsește din dicționare.

Este un derivat, cu suf. verbal -ni, de la interjecția jup 'buf, jap, zup', dată de același informator, necunoscută de dicționare. Ne este familiară din Bonțida (satul natal) CJ, Năsal CJ etc. De la ea s-au mai format a jupăi 'a bate', a jupi 'idem' (vezi Loșonți CIE 121).

JUVĂÍ. $A$ juvăi a fost notat de Emil Petrovici în Vânători MS, cu sensurile 1. '(despre ape) a vâjâi' (juvăie: ALR II SN V h. 1460/157) și 2. '(despre pădure în furtună) a vui' (juvăie: ibid. h. 1461/157).

$\mathrm{Nu}$ se găsește în dicționare.

Teoretic s-ar putea explica, prin sonorizarea lui ș, din şuvăi $=$ șovă ${ }^{2}$ 'a șuiera; a vâjâi; a vui”, pe care DLR îl dă cu etimologia necunoscută, raportându-1 la a șovăi ${ }^{1}$, cu care nu înțelegem ce legătură ar putea avea. Sonorizarea lui ș o constatăm și în a jujoti '(despre ape) a vâjâi' (ALR II SN V h. 1460/334 < a șușoti. În acest caz nam putea explica cum s-au format $a$ șuvăi $=a$ șovăi ${ }^{2}$.

$\mathrm{N}$-ar fi exclus a juvăi să fie o variantă metatezată a lui *a vujăi (cf. a vujoi, variantă a lui $a$ vâjâi: DLR), formă foarte probabilă. Din a juvăi și *a jovăi $(<a$ vojăi, notat în mai multe puncte vecine sau apropiate de Vânători; vezi harta 1460 citată mai sus) se pot explica $a$ șuvăi $=a$ șovă ${ }^{2}$, prin pierderea sonorității lui $j$.

LEOÁPĂ e lucrat în DLR cu sensurile 1. (Bucov., Mold. şi prin Trans.) gură (ca organ al vorbirii); (popular) leoarbă (1)'; 2. '(prin Trans.) lovitură dată cu palma' și explicat ca ,postverbal de la a leopăi”".

Considerăm că sensul al II-lea e derivat direct de la interjecția leoap (lioap) 'poc, pleosc, trosc, zup', variantă a lui leop, atestată de Emil Petrovici în Voiniceni MS și Bocşa SJ (ALR II SN V h. 1468/235, 279), absentă nejustificat din DLR.

MORNĂÍ. Forma verbală a mornăi '(regional; despre albine și muște) a bâzâi, a zumzăi', cunoscută de DLR din ECONOMIA, 193/14 și din Sânmihaiu Almașului SJ (vezi ALR II SN V h. 1463/284) nu trebuia lucrată la $a$ mornăi $=a$ mormăi (<mor $m[$ or]), pentru că a rezultat, prin substituirea lui $b$ - cu $m$-, din $a$ bornăi, verb notat în puncte vecine cu Sânmihaiu Almașului (vezi harta citată).

Pentru substituirea lui $b$ - (inițial) cu $m$-, vezi Andrei Avram, Probleme de etimologie, București, Editura Univers Enciclopedic, 2000, p. 53-69.

PIRUÍ. Forma verbală a pirui '(despre păsări) a ciripi’, notată de E. Petrovici în Prundu Bârgăului BN ([pĉíruiẹ̌]: ALR II SN V h. 1462/219), lipsește nejustificat din DLR. 
O interjecție *pir, care să imite ciripitul păsărilor, nu e atestată și, poate, nici nu e posibilă.

Cel puțin teoretic, a putut rezulta prin metateză din a piuri 'a piui', iar această variantă provine, cum bine arată și Vasile Frățilă, Etimologii. Istoria unor cuvinte, București, Editura Univers Enciclopedic, 2000, p.73-74, prin schimbare de conjugare, din piura < lat. piulare.

ROMȚÂÍ, RONȚĂNÍ sunt date în DLR ca variante ale lui $a$ ronțăí, cuvânt bine derivat de interjecția ,ronț + suf. -ăì".

A ronțăni trebuia lucrat în articol separat, pentru că e derivat de la ronț, dar cu suf. -ăni.

Considerăm că și a romțâi este cuvânt de sine stătător. S-a format prin contaminarea sinonimelor a rompăi, înregistrat într-un punct vecin (vezi ALR II SN IV h. 1069/29) și a scârțâi. Nici harta citată, nici DLR nu atestă o variantă (de altfel posibilă) *a ronțâi, cu care să se fi contaminat a rompăi.

ROȘCĂNÍ '(despre zăpadă), a scârțâi sub picioare' a fost notat de Emil Petrovici în Livezi HR (roșcănéște: ALR II SN V h. 1469/574).

În DLR se arată că este o „formație onomatopeică”.

Este un derivat, cu suf. - $\breve{a n i}$, de la interjecția *(h)roşc.

ȘIRĂÍ, ȘIRLOÍ, ȘIROÍ, ȘIROIÁ, ȘIRUÍ, ȘÚRA, ȘURĂÍ, ȘUROÍ, ȘURUÍ. În DLR s-a lucrat verbul $a$ șiroi ${ }^{3}$ 1. '(despre ape) a curge cu repeziciune, producând un zgomot caracteristic'; 2. '(despre lichide) a curge, a se prelinge în șuvițe (abundente) de undeva sau din ceva (producând un zgomot caracteristic)', cu variantele $a$ șirăi a șirloi, a șiroia a a șirui, a șurăi a a șuroi, a șurui.

În paragraful etimologic, după mențiunea „formație onomatopeică”, este comparat cu a ciurui.

Forma originară (din care se explică celelalte prin asimilare, ,despicare”, eventual substituire de sufix, influența lui șir) este $a$ șurăi , un derivat, cu suf. -ăi , de la interjecția şur, cunoscută de acest dicționar din Banat și Muntenia cu sensul 'cuvânt care redă zgomotul produs de curgerea apei'. În alte părți, de exemplu în Bucovina, ea redă zgomotul făcut de datul cu picioarele pe gheață, cum rezultă din $a$ se şurăi (literalizat $a$ se șurai într-un grai în care $\breve{a}$ protonic este substituit cu $a$ ) 'a se da pe gheață' („Nu vă mai șuraiți atâta măi, că s-a rupe gheața pe părău”: I. Popescu-Sireteanu, Glosar dialectal din Bucovina și Moldova, Iași, Editura Printis, 2013, p. 123).

Șura, substantiv întrebuințat în locuțiunea verbală a se da de-a şura'a se șurăi, a se da pe gheață' (ibid.) este un derivat regresiv de la a se șurăi. Cf. sinonimele șuia, șuiul în a se da (pe gheață) de-a șuia/șuiul < a se șui (vezi Loșonți CPE 399).

ȘTERICĂÍl. Forma verbală a ștericăi 'a ciripi', înregistrată în Pecinișca CS ([șćẹrícăiěe]: ALR II SN V h. 1462/2), lipsește nejustificat din DLR.

Este o variantă a lui a ciricăi 'idem', verb atestat în puncte vecine sau apropiate (vezi harta citată), rezultată sub influența lui șterică, variantă a lui știrică 'coțofa- 
nă', ambele forme fiind notate în Jupalnic CS (vezi ALRR-Banat III h. 456/1), punct de anchetă vecin cu Pecinișca.

ŞÚIET 'zgomot (slab, continuu și monoton) produs de curgerea unei ape, de bătaia vântului, de foșnetul frunzelor etc.' a fost considerat „onomatopee [cf. șuvoiu]” (DU), „cuvânt fabricat” (SDLR), derivat „din șu + suf. -et” (DM), „probabil contaminare între șuier și vuiet” (DEX $\left.{ }^{1,2}, \mathrm{MDA}\right)$, „formație onomatopeică. Cf. şuşui ${ }^{2 "}$ (DLR), cuvânt „onomatopeic” (BDG). CADE și CDER nu-1 înregistrează.

E un derivat, cu suf. -et, de la verbul a se șui, necunoscut de DLR, care, la rândul lui, s-a format, cu sufixul verbal $-i$, de la interjecția șu (vezi Loșonți CPE 399). Cf. sinonimul vuiet < a vui (DLR).

ȘURUÍ1. Verbul a șurui ‘(despre frunze) a fâșâi’ a fost înregistrat de Sever Pop în Nojorid BH (ALR I 963/320).

În DLR și MDA, după precizarea „formație onomatopeică”, este comparat cu interjecția şur.

Fără nicio îndoială, este derivat de la aceasta, cu suf. -ui. Cf. $a$ burui $<$ bur, $a$ ciurui < ciur, a durui < dur, a hurui < hur etc.

ȘUȘUÍ, ȘUȘUIÁ. Forma verbală $a$ șușuia a fost înregistrată de Sever Pop, în Balotești VR, ca răspuns la întrebarea „Când copilul mic plânge tare, ce faceți?” (îl șușui, l-am șuşuiat: ALR I/II h. 237/596). Lipsește nejustificat din DLR. Acolo este doar varianta de conjugarea a IV-a, a şuşui, cu sensurile: 1. '(despre frunzele mișcate de vânt, despre ape etc.) a produce un zgomot slab (și continuu); a șoșoi ${ }^{22 "}$; 2. '(complementul indică copii) a liniști sau a adormi prin repetarea prelungită și monotonă a sunetului „ș”; a șâșâi'; 3. 'a șopti'. E considerată „formație onomatopeică. Cf. şu”.

Provine din şu şu, cu suf. verbal $-i$.

TĂRĂIRÁM 'ceartă, tărăboi, scandal' a fost comunicat din fostul raion Orăștie HD (vezi LRg II 102).

În DLR și MDA, după mențiunea „formație onomatopeică”, este comparat cu interjecția tara 'cuvânt care imită vorbărie multă, fără rost'.

După părerea noastră, a putut rezulta atât din contaminarea acestei interjecții cu bairam 'chef mare, veselie (zgomotoasă)', cât și din contaminarea sinonimelor tărăboi și bairam.

TROSNÍ (TROZNÍ). A trosni 1. '(mai ales despre lemne sau obiecte de lemn) a produce un zgomot caracteristic prin rupere, prăbușire, ardere, apăsare, izbire, din cauza gerului sau a căldurii prea mari; a crăpa, a pocni, a pârâi, a plesni cu zgomot'; 2. (subiectul indică părți din corp) a pârâi din încheieturi' a fost explicat ca variantă a lui a trăsni 'a se produce trăsnet' (DU, SDLR), din a trăsni (TDRG ${ }^{1,3}$, 
[cu probabilitate] CADE) sau comparat cu a trăsni (DEX ${ }^{1,2}$, DLR, BDG și [după mențiunea că etimologia este nesigură] MDA. În DM se trimite la a trăsni. CDER îl lucrează între derivatele de la interjecția trosc, cu observația: ,probabil în loc de *troscni, cu suf. expresiv -ni".

Fără nicio îndoială, a rezultat din *troscni $(<\operatorname{trosc}+-n i)$, prin reducerea grupului consonantic -scn- la -sn-. Cf. supra a fleosni.

ȚẤŞCĂ, ȚÂŞCĂÍl. Substantivul țâşcă, atestat în sintagma țâșcă cu apă 'pușcă cu apă; pușcoci', este derivat în DLR și MDA de la verbul „a țâști + suf. -că’", iar verbul a țâșcâi '(regional; despre lichide) a țâsși cu zgomot' este considerat formație onomatopeică și comparat cu interjecția țaşsti.

Pe lângă țâșt, țaşsti a existat (sau mai există) și forma interjecțională *țâșc. Cf. țâr, țârc; țin, *ținc (> ting); vârc etc.

Țâșcă s-a format de la *țâșc prin contaminare cu (sau sub influența sinonimului) pușcă (cu apă), iar a țâșcâi e derivat de la *țâșc, cu suf. -âi .

ȚINĂÍ́. Verbul a ținăi (prin Mar. și nord-vestul Trans.; despre obiecte) a produce un sunet ascuțit și prelungit', '(despre ureche) a-i țiui cuiva' este lucrat în DLR cu varianta a zinăi și considerat formație onomatopeică.

Este derivat, cu suf. -ăi , de la interjecția țin. Aceasta, pe lângă sensul (atestat) 'cuvânt care redă sunetul scos de pitulice', le are (sau le-a avut) și pe cele care redau 1. un sunet ascuțit și prelung scos de obiecte din metal ori din sticlă lovite (unul de altul); 2. sunetul clopotului ori 3. țiuitul urechii.

ȚORCĂÍ, ȚORCOTÍ. Ambele cuvinte înseamnă 'a suge făcând zgomot cu buzele' și sunt considerate în DLR formații onomatopeice.

După părerea noastră, sunt derivate cu sufixele -ăi, respectiv -oti, de la *torc, variantă a interjecției țoc 'cuvânt care imită zgomotul produs de sărut sau de supt' (vezi DLR).

VÂJNÍ, VÂȘNÍ. Verbul a vâjni '(regional) a zvâcni', cu varianta a vâșni, comparat în DLR și MDA cu interjecția vâj și cu verbul $a$ vâjâi, este derivat, cu suf. verbal -ni, de la interjecția vâj.

VÂȘCÁ，VÂȘCĂÍ， VÂȘCĂRí，VÂȘCÂÍ，VÂȘGĂÍ. În DLR s-au lucrat verbele $a$ vâşca ${ }^{1}$, cu sensul principal (foarte bine atestat) '(Trans., Mold. și Bucov.; mai ales în construcții negative) a se mișca; a se foi; a se agita, a se zbate să scape', verb lăsat cu ,etimologia necunoscută”, dar comparat (și în MDA) cu ucr. вештатися, și (pe baza unei atestări din Sanislău SM) vâșca '(despre ființe) a se mișca brusc, a porni în grabă, a țâş̧i din locul în care se află', raportat, pentru etimologie, la $a$ vâști.

$\mathrm{Nu}$ încape nicio îndoială că nu-i vorba de două cuvinte, ci de unul singur, provenit, cu suf. verbal - $a$, de la interjecția vâșc 'cuvânt care sugerează o mișcare bruscă, rapidă’, cunoscută de acest dicționar de prin Transilvania. 
La vâșca ${ }^{1}$ sunt date ca variante regionale vâșcăi vâșcărí, vâșcâí, vâșgăi , vâscá, vâscărí, vâsgăi vișgăi și vușcá.

Formele cu $s$ sunt suspecte.

A vâșcăi, a vâșcări și a vâșcâi sunt cuvinte de sine stătătoare, formate cu suf. - $\breve{a} i$, -ări, respectiv -âi , tot de la interjecția vâșc, iar $a$ vâjgăai, a vişgăi au rezultat din vâșcăi , prin sonorizarea lui $c$.

VÂȘCOLÍ '(prin estul Banatului) a se mișca, a se foi', lăsat în MDA cu etimologia necunoscută și comparat în DLR cu $a$ vâșca $a^{1}$, este derivat, cu suf. -oli, de la interjecția vâșc.

VIȚIÍ e lucrat în MDA și DLR cu variantele vițăí, vițâí, vițeí și vițuí și raportat la covițâi. Fără îndoială că s-a format, prin afereza primei silabe, din a covițăi (cf. și Marin Verbe... 21).

ZÂRÂÍ. Verbul $a$ zârâi '(prin vestul Trans.; în expresia $a$-i zârâi urechea) a-i țiui urechea' e dat în DLR și MDA cu mențiunea „formație onomatopeică”.

E derivat, cu suf. -âi, de la interjecția *zâr 'zor, zur'. Cf. dâr, dur; hâr, hur (vezi Loșonți CPE 412); țâr, țur etc.

ZÂZĂÍ, ZÂZÂí, ZIZĂÍ́. A zâzâii este lucrat în DLR și MDA cu sensurile 1. '(despre insecte, mai ales despre muște și albine) a bâzâi'; '(regional; despre trestie) a produce un anumit zgomot sub bătaia vântului'; 2. '(despre oameni) a pronunța defectuos anumite sunete, făcând să se audă ca „z”; (regional) a șișcăvi ${ }^{1}$, și variantele a zâzăi a zizăi

După mențiunea „formație onomatopeică”, este comparat cu a bâzâi.

A zâzâi, este derivat, cu suf. -âi, de la interjecția *zâz 'bâz'. Cf. infra* zuz.

$A$ zizăi este variantă, dar a lui $a$ zâză $i$, care este verb de sine stătător, derivat, cu suf. -ăi , de la *zâa.

ZDÂGNí, ZDOCNí, ZDOHNí, ZDUCNí, ZDUGNí, ZDUHNí. CADE înregistrează verbul a zducni (var. a zdugni) 'a zdruncina, a zgudui' fără explicație etimologică. În DLR și MDA, a zducni (var. a zdâgni, a zdocni, a zdohni, a zdugni, a zduhni) figurează cu sensurile 1. '(prin Banat) a zdruncina; p. e x t. a izbi cu putere'; 2. '(reg.) a cădea'; 'a ieși din locul unde se află'; 3. '(prin Trans., prin vestul Munt. și prin Dobr.; mai ales despre animale) a muri' și etimologia necunoscută.

$\mathrm{Nu}$ ne putem da seama ce legătură au putut vedea redactorii dicționarului între primele două sensuri și cel de-al treilea.

Sensurile 1 și 2 aparțin unui cuvânt a cărui formă originară este zducni, (> zdâgni, zdugni, zduhni).

Acesta este un derivat, cu suf. - $n i$, de la interjecția * $z d u c$ 'zdup'. Cf. interjecțiile ciric, cirip. 
Sensul al treilea, atestat la formele zdocni, zdohni, zducni, zduhni aparține unui alt cuvânt, explicat în SDLR (s.v. zduhnesc) din rus. za-dóhnutĭ-sěa 'a-și da sufletul'.

ZDUPÍ '(despre sacul plin când cade) a produce un sunet caracteristic' (Petrila HD: ALR II SN V h. 1468/833) este un derivat, cu suf. - $i$, de la interjecția $z d u p$.

Lipsește nejustificat din DLR.

Tot nejustificat lipsește din DLR atestarea sensului 'a zdupi' la derivatul $a$ zdupăni (vezi harta citată, punctul 812), cunoscut din Segarcea și Berzovia doar cu sensul 'a tropăi'.

ZGORȚĂÍ '(despre zăpadă) a scârțâi sub picioare’ (Borșa MM: ALR II SN V h. 1469/362) lipsește nejustificat din DLR.

Provine, prin sonorizarea grupului consonantic sc, din a scorțăi 'idem', verb cunoscut de dicționare, notat și în punctul vecin Ciocănești SV (ibid. h. 1469/365), un derivat, cu suf. -ăi, de la interjecția scorț, lucrată în DLR ca variantă a lui scârț. În Borșa, interjecția are forma scoarț [scǫrț] (vezi răspunsul complet din punctul citat).

ZGRUNȚǍÍl. $A$ zgrunțăi '(despre nisipul din pâinea făcută din făina măcinată după ce a fost ferecată roata morii) a trosni (în dinți)', notat de Emil Petrovici în Pecica AR (vezi ALR II SN IV h. 1069/53), lipsește nejustificat din DLR.

S-a format, cu suf. verbal -ăi, de la interjecția zgrunț 'onomatopee care imită zgomotul produs de un obiect care se sparge', cunoscută de DLR, sau, cu z(protetic), din grunțăi 'a ronțăi', verb considerat în DA ,onomatopee” și comparat cu a ronțăi.

Interjecția zgrunț este greșit lucrată în DLR și MDA în același articol cu zgrunț 'grunz'. E vorba de două cuvinte total diferite.

Zgrunț 'grunz' este una din variantele lui grunz, cuvânt moștenit din lat. grundeus, după cum a arătat Giovanni Alessio în Lexicon Etymologicum. Supplemento ai dizionari etimologici latini e romanzi, Napoli, Arte tipografica, 1976.

Zgrunț, ca interjecție, este o variantă, cu z- (protetic) a lui * grunț, de la care s-a format a grunțăi.

Verbele a zgronțăi și a zgronțăni, cunoscute prin nord-vestul Munteniei cu sensurile 1. 'a ronțăi; a scrâșni; 2. 'a scârțâi', sunt derivate în DLR și MDA de la zgronț + suf. -ăai, respectiv -ăni, dar, curios lucru, zgronț figurează în aceste dicționare doar ca substantiv neutru, nu și ca interjecție. Fără îndoială că sunt derivate de la interjecția *zgronț, variantă, cu $z$ - (protetic) a lui * gronț, care este perechea (cu velara sonoră) a lui cronț, de la care avem derivatele (cunoscute de MDA) $a$ cronțăi 'a ronțăi' și a cronțăni 'idem'.

ZORĂÍ́, ZURUÍ. În DM, DEX ${ }^{1,2}$, DLR și MDA, verbul a zurăi 1 . '(de obicei despre obiecte confecționate din metal sau din sticlă sau despre părți componente ale unor astfel de obiecte) a produce un sunet caracteristic când se mișcă, când se 
ciocnește de ceva sau când este lovit cu ceva; p. e x t. a produce zgomote (supărătoare)'; 2. '(popular și familiar; despre ape curgătoare, ploaie, frunze sau alte elemente ale naturii) a murmura, a susura' este considerat variantă a lui a zurui (< $z u r+$ suf. $-u i)$.

După părerea noastră, este un verb independent, derivat cu suf. -ăi, de la interjecția zur.

Considerăm că și a zorăi trebuia lucrat în articol separat, verbul fiind derivat, cu suf. - $\breve{a} i$, de la interjecția zor 'zur'.

ZORZOÍ, ZORZONÍ. A zorzoi 'a zăngăni' nu provine de la zor', cum greșit dau DLR și MDA (zor ${ }^{1}$ fiind substantiv însemnând 1. 'silnicie'; 2. 'activitate însuflețită, febrilă' etc.), ci, cum se arată în $\mathrm{DEX}^{1,2}$, de la interjecția zor [în $\mathrm{DEX}^{1,2}=$ $z o r^{2}$, în DLR și MDA = zor $\left.{ }^{3}\right]:, z o r^{2}+z\left[\right.$ or $\left.^{2}\right]+$ suf. $-o i "$.

Sinonimul a zorzoni, explicat parțial de DLR ,de la $z o r^{3}$ " și de MDA „de la $z o r "$, s-a format de la $z o r^{3}+z\left[\right.$ or $\left.^{3}\right]+$ suf. -oni.

ZUĂÍ, ZUHĂÍ. Verbul a zuăi '(învechit și regional; despre insecte) a zumzăi' este derivat corect în DLR din interjecția $z u$ şi suf. -ăi. Precizăm doar că $z u$ este o interjecție independentă, nu una provenită din zum, cum se indică în dicționar.

A zuhăi, formă verbală notată de Emil Petrovici în Vânători MS (vezi ALR II SN V h. 1463 [nu 1436]/157), sat aflat la marginea secuimii, poate fi, într-adevăr, o

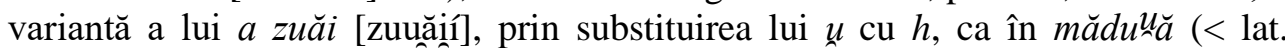
medulla) > măduhă.

Dar, cum în Vânători „toată lumea [e] bilingvă, și români și unguri” (Emil Petrovici, Atlasul lingvistic român II. Introducere. Redactori: Doina Grecu, I. Mării, Rodica Orza. Coordonator: I. Mării, Cluj-Napoca, 1988, multiplicat, p. 86), este posibil ca $a$ zuhăi să provină (prin substituirea, destul de frecventă, a lui $g \mathrm{cu} h$ ) din *a zugăi, un derivat de la ung. zúg 'a zumzăi' și suf. rom. -ăi.

ZUMZĂÍ, ZUMZÍ. A zumzăi 1. '(despre insecte, mai ales despre albine și muște) a produce un sunet caracteristic zborului; p. e x t. (rar) a zbura, a bâzâi' și $a$ $z u m z i$ 'a murmura, a fâşâi' sunt explicate incomplet în DLR și MDA ,de la zum”.

Sunt derivate, cu sufixele verbale -ăi , respectiv -i, de la zum $z$ [um] (cf. și DEX ${ }^{1}$ ).

ZÚRĂT 'zornăială' este derivat în DLR și MDA de la interjecția zur, cu suf. -ăt.

Credem că e derivat de la verbul a zurăi. Cf. zumzet $<$ a zumzăi, zuzet $<$ a zuzăa etc.

ZUZĂÍ, ZUZĂNÍ, ZUZINÍ, ZUZUÍ. Verbul a zuzui 1. '(despre insecte, mai ales despre albine) a zumzăi'; 2. '(rar, despre ape, despre izvoare, despre valuri etc.) a murmura, a susura; (rar, despre vânt) a șuiera'; 3. '(învechit și popular, despre obiecte din metal, de sticlă etc.) a zurui' este considerat „onomatopee” (DM), ,formație onomatopeică” (DEX ${ }^{1,2}$, DLR, MDA). 
După părerea noastră, este un derivat, cu suf. -ui, de la interjecția *zuz (cf. bâz, $v \hat{a} j)$.

A zuzăi, a zuzăni și a zuzini nu sunt variante ale lui a zuzui, ci verbe de sine stătătoare, formate de la interjecția *zuz cu sufixele - $\breve{a} i$, -ăni, respectiv -ini. Pentru acest din urmă sufix, vezi Vasiliu DV 89-91.

Cât privește forma $a$ zizăi, aceasta este variantă, dar nu a lui $a$ zuzui, ci (cum e și dată) a lui $a$ zâzăi

\section{ABREVIERI BIBLIOGRAFICE. SIGLE}

ALR I = Material inedit adunat de Sever Pop pentru Atlasul lingvistic român, partea I.

ALR I/II = Atlasul lingvistic român publicat... de Muzeul Limbii Române din Cluj, sub conducerea lui Sextil Pușcariu. Partea I, vol. II, de Sever Pop, Sibiu-Leipzig, 1942.

ALR II SN = Atlasul lingvistic român [II], serie nouă, IV, V, [București], Editura Academiei Române, 1965,1966

ALRR-Banat III = Atlasul lingvistic român pe regiuni. Banat, III, sub conducerea lui Petru Neiescu, de Eugen Beltechi, Ioan Faiciuc, Nicolae Mocanu, București, Editura Academiei Române, 1998.

Bărbuț DGO = Dorina Bărbuț, Dicționar de grai oltenesc, Craiova, Asociația Independentă Literară, Artistică, Culturală și Editorială „Mileniul III”, 1990.

BDG = Vasile Breban, Dicționar general al limbii române. Ediție revăzută și adăugită, I, II, Bucuresti, Editura Enciclopedică, 1992.

$\mathrm{CADE}=$ Dicționarul enciclopedic ilustrat , Cartea Românească”. Partea I: Dicționarul limbii române din trecut și de astăzi, de I.-Aurel Candrea, [...] București, Editura Cartea Românească, [1931].

$\mathrm{CDER}=$ Alexandru Ciorănescu, Dicționarul etimologic al limbii române, București, Editura Saeculum I. O., 2001.

CHEST. II = Răspunsuri la Chestionarul II. Casa, Sibiu, 1926 (cifra arabă de la numărător arată numărul chestiunii, cea de la numitor, numărul de ordine al localității.)

CHEST. IV = Răspunsuri la Chestionarul IV. Nume de loc și nume de persoană, Cluj, 1930 (cifra arabă de la numărător arată numărul chestiunii, cea de la numitor, numărul de ordine al localitătii. În unele localități, pe lângă răspunsurile la întrebările chestionarului, s-au comunicat, de obicei la sfârșit, ca adaos, și alte cuvinte. În cazul unui asemenea cuvânt, în locul numărului întrebării se dă abrevierea Ad. [ = Adaos].)

Ciaușanu Gl = G. F. Ciaușanu, Glosar de cuvinte din județul Vâlcea, București, Regia M. O., Imprimeria Națională, 1931 (Academia Română. Memoriile Secțiunii literare. Seria III. Tomul V. Mem. 6).

Cihac I, II = A. de Cihac, Dictionnaire d'étymologie daco-romane, [vol. I.]. Éléments latins, comparés avec les autres langues romanes, Francfort s/M., 1870; [vol. II.]. Éléments slaves, magyars, turcs, grecs-moderne et albanais, Francfort s/M., 1879.

Coman Gl = Petre Coman, Glosar dialectal, București, Monitorul Oficial și Imprimeriile Statului. Imprimeria Națională, 1939 (Academia Română. Memoriile Secțiunii literare. Seria III. Tomul IX. Mem. 5).

DA = Dicționarul limbii române [publicat de Academia Română, sub redacția lui Sextil Pușcariu], București, 1913-1949.

DELR = Dictionarul etimologic al limbii române (DELR). Volumul I, $A-B$. Tiraj nou, revizuit, București, Editura Academiei Române, 2012; Volumul II. Litera C. Partea 1, Ca-Cizmă, București, Editura Academiei Române, 2015. 
DEX $^{1,2}=$ Dicționarul explicativ al limbii române, [București], Editura Academiei 1975; ediția a II-a, București, Editura Univers Enciclopedic, 1996.

DLR = Dicționarul limbii române, serie nouă [publicat de Academia Română], tomul VI [M], București, 1965 ș. u.

$\mathrm{DM}=$ Dicționarul limbii române moderne, [București], Editura Academiei, 1958.

DU = Lazăr șăineanu, Dicționar universal al limbei române. A cincea edițiune, revăzută și adăogită, [Craiova], Editura „Scrisul Românesc” S. A., [1925].

Faiciuc D = Elisabeta Faiciuc, Dragomirești între tradiție și modernism. Ediția a doua, revizuită și adăugită, a monografiei, cu o Antologie de folclor și Considerații muzicale, de Elena HlincaDrăgan, Cluj-Napoca, Editura Limes, 2008.

FCLR IV/1 = Formarea cuvintelor în limba română. Volumul al IV-lea. Derivarea nominală și adverbială. Partea 1. Coordonator: Marina Rădulescu Sala, București, Editura Academiei Române, 2015.

Király Contacte $=$ Király Francisc, Contacte lingvistice. Adaptarea fonetică a împrumuturilor românești de origine maghiară, Timișoara, Editura Facla, 1990.

$\mathrm{LB}=$ Lesicon românesc-lătinesc-unguresc-nemțesc, care de mai mulți autori, în cursul a trideci și mai multor ani s-au lucrat, seu: Lexicon valachico-latino-hungarico-germanicum quod a pluribus auctoribus decursu triginta et amplius annorum elaboratum est, Budae, 1825.

Loșonți CEL II = Dumitru Loșonți, Contribuții etimologico-lexicale (II), în Lucrările celui de-Al XVII-lea Simpozion Internațional de Dialectologie (Cluj-Napoca, 8-9 sept. 2016), Cluj-Napoca, Editurile Argonaut și Scriptor, 2018, p. 150-169.

Loșonți CIE = Dumitru Loșonți, Certitudini și ipoteze etimologice, București, Editura Academiei Române, 2007.

Loșonți CPE = Dumitru Loșonți, Convingeri şi propuneri etimologice, București, Editura Academiei Române, 2021.

LRg I, II = Lexic regional, I, București, Editura Academiei, 1960; II, București, Editura Științifică, 1967.

Marin Verbe $=$ Georgeta Marin, Verbe derivate de la interjecții onomatopeice, în SMFC IV, 1967, p. 217-234.

MCD I = Materiale și cercetări dialectale, I, [București], Editura Academiei, 1960.

MDA = Micul dicționar academic, I-IV, București, Editura Univers Enciclopedic, 2001-2003.

Pascu Suf. = Dr. G. Pascu, Sufixele românești, București, Edițiunea Academiei Române, 1916.

Popa Voroave = Liviu Popa, Voroave bătrânite din izvorul dacic al Orăștiei, Iași, Editura Pim, 2016.

Pușcariu DO $=$ Sextil Pușcariu, Din perspectiva Dicționarului. I. Despre onomatopee în limba română, în „Dacoromania”, I, 1920-1921, p. 73-108.

SDLR = August Scriban, Dicționaru limbii românești, Iași, Institutu de Arte Grafice „Presa Bună”, 1939.

SMFC III, IV = Studii și materiale privitoare la formarea cuvintelor în limba română, III, IV, București, Editura Academiei Române, 1962-1967.

Tamás E = Lajos Tamás, Etymologisch-historisches Wörterbuch der ungarischen Elemente im Rumänischen (unter Berücksichtigung der Mundartwörter), Budapesta, Akadémiai Kiadó, 1966.

$\mathrm{TDRG}^{1,3}=$ Dr. H. Tiktin, Rumänisch-deutsches Wörterbuch, [Band I-III], Bukarest, Staatsdruckerei, 1903-1924; 3., überarbeitete und ergänzte Auflage von Paul Miron und Elsa Lüder, Bukarest, Band I: $A-C$, Band II: $D-O$, Band III: $P-Z$, Cluj-Napoca, Clusium, 2000-2005.

Tomoiagă ARM = Tomoiagă Gheorghe Hovrea, Arhaisme și regionalisme din Moisei, Petrova, Editura Țara Maramureșului, 2016.

Vasiliu DV = Laura Vasiliu, Formarea cuvintelor în limba română. Volumul al III-lea. Sufixele. 1. Derivarea verbală, [București], Editura Academiei, 1989. 
ALTE ABREVIERI

$\begin{array}{llll}\begin{array}{ll}\text { Bucov. } \\ \text { cf. }\end{array} & \text { Bucovina } & \text { p. e x t. } & =\text { prin extensiune } \\ \text { com. } & \text { = (lat.) confer 'compară' } & \text { pers. } & =\text { persoană } \\ \text { h. } & \text { comună } & \text { pl. } & =\text { plural } \\ \text { ibid. } & \text { hartă, hărți } & \text { reg. } & =\text { regional } \\ \text { interj. } & \text { = ibidem } & \text { rus. } & =\text { rusesc, rusă } \\ \text { lat. } & \text { = latin(ă) } & \text { s.v. } & =\text { (lat.) sub voce 'sub } \\ \text { MN } & \text { = material necartografiat } & \text { cuvântul' } & \\ \text { Mold. } & \text { = Moldova } & \text { suf. } & =\text { sufix } \\ \text { Munt. } & \text { = Muntenia } & \text { Trans. } & =\text { Transilvania } \\ \text { nr. } & \text { = număr } & \text { ucr. } & =\text { ucrainean(ă) } \\ \text { Olt. } & \text { = Oltenia } & \text { ung. } & =\text { unguresc } \\ \text { p. } & \text { = pagină } & \text { var. } & =\text { variantă } \\ & & \text { vol. } & =\text { volum }\end{array}$

\section{SIMBOLURILE PENTRU JUDEȚE}

$\begin{array}{ll}\mathrm{AB} & =\text { Alba } \\ \mathrm{AR} & =\text { Arad } \\ \mathrm{BH} & =\text { Bihor } \\ \mathrm{BN} & =\text { Bistrița-Năsăud } \\ \mathrm{CJ} & =\text { Cluj } \\ \mathrm{CS} & =\text { Caraș-Severin } \\ \mathrm{GJ} & =\text { Gorj } \\ \mathrm{HD} & =\text { Hunedoara } \\ \mathrm{HR} & =\text { Harghita }\end{array}$

$\begin{array}{ll}\text { MM } & =\text { Maramureș } \\ \text { MS } & =\text { Mureş } \\ \text { SB } & =\text { Sibiu } \\ \text { SJ } & =\text { Sălaj } \\ \text { SM } & =\text { Satu Mare } \\ \text { SV } & =\text { Suceava } \\ \text { VL } & =\text { Vâlcea } \\ \text { VR } & =\text { Vrancea }\end{array}$

În cazul unor cuvinte sau sensuri menționate după DA sau DLR, am indicat și sursele de unde aceste dicționare le extrag, utilizând abrevierile lor.

\section{WORDS DERIVED FROM ONOMATOPOEIAS (II) (Abstract)}

In this paper I aim to analyse a number of words derived from onomatopoeias or regarded as such. Some of these have been given appropriate treatment in dictionaries, while others have received either mistaken or insufficient explanations in the relevant literature.

Making use of some of the data which Emil Petrovici collected for Atlasul lingvistic român II, I identify the interjections from which the words under analysis were derived and describe the formation of these derivatives.

Cuvinte-cheie: dicționare, etimologie, formație onomatopeică, interjecție, onomatopee.

Keywords: dictionary, etymology, interjection, onomatopoeia, word formation

Institutul de Lingvistică și Istorie Literară „Sextil Puşcariu” al Academiei Române Cluj-Napoca, str. E. Racoviță, 21 